\title{
MMP2 Gene
}

National Cancer Institute

\section{Source}

National Cancer Institute. MMP2 Gene. NCI Thesaurus. Code C26514.

This gene is involved in angiogenesis, inflammation and the regulation of extracellular matrix remodeling. 